\title{
A Dialogue on
}

\section{The Literary Mind / The Core of Writing 論 “文心”一—西對話}

Alessandra C. Lavagnino 蘭珊德

DOI: http://dx.doi.org/10.7359/825-2017-lav1

\section{ABSTRACT}

The title of this volume, Wenxin Duibua 文心對話: A Dialogue on The Literary Mind / The Core of Writing, recalls the title of the International Symposium organized by the Confucius Institute of the University of Milan - thanks to the generous help of Hanban - at the Department of Language Mediation and Intercultural Communication, in May 2014. This title may sound quite unusual to a Western reader, owing to the limited familiarity with the Chinese literature in our world. It is true indeed that China today is an increasingly hot topic: its rapid economic development, the spread of its social transformation, the new signs of a different process of modernization amaze us and at the same time alarm us. Nevertheless, all this seems to overshadow its great cultural heritage, its important written tradition, the literature and poetry of classical China, a very wide field which, in Italy until now, has been largely unexplored. This is the reason why the title we decided to give our Symposium - which is taken from a masterpiece of Chinese literary criticism, Wenxin diaolong 文心雕龙 (WXDL $)^{1}$, written at the beginning of the VI century A.D. by Liu Xie 刘称 - is almost unknown to our readers ${ }^{2}$. In fact, we decided to take this

1 For the various translations of chapters titles, see Simona Gallo, "Decoding and Recoding Decoding and Recoding Signs and Images of Wenxin Diaolong: from Title to Titles" (pp. 99-113).

2 The WXDL contains approximately 37.000 characters. It is divided into ten juan 卷, each consisting of five chapters, carrying a descriptive title. It is written in pian wen 駢文 or pianti wen 駢體文 (parallel prose), “[...] a technique employed in the writing of extra-poetic literary genres. Its most salient features are a preponderance 
book as a starting point to initiate a dialogue (duibua 對話) between some Chinese and Western scholars on common themes of writing, poetry, literary criticism, because this masterpiece perfectly represents the Chinese traditional views on those important themes, views which are still shared and revered in today's China. Our choice was dictated on the one hand by our fascination for this text but, almost more importantly, it was motivated by the fact that WXDL is the first and unquestioned, systematic compendium of Chinese literary thinking, and the first systematic categorization of literary knowledge in traditional China.

Keywords: international Symposium, Wenxin diaolong, dialogue, literary thinking, today's and traditional China.

\section{摘要}

論文集題為 “文心對話”。論 “文心”一中西對話。回顧了於2014年5月在米蘭國立大學 跨語言文化交流學院, 由米蘭國立大學孔子學院組織舉辦的國際研討會。此次研討會得到 了中國國家漢辦的慷慨幫助。由於西方世界對中國文學的熟悉程度有限, 這個題目對西方 讀者來說可能有些陌生。的確, 當今中國是一個越來越熱門的話題, 經濟快速發展、社會 轉型擴大、不同現代化進程的新跡象令我們驚歎不已。然而, 這一切似乎都掩蓋了其偉大 的文化遺產, 其重要的書面傳統-中國古典文學和詩歌, 這是一個非常廣泛的領域, 在義大 利, 到目前為止, 很大程度上還未被探索。這也是為什麼我們決定把研討會命名為 “文心

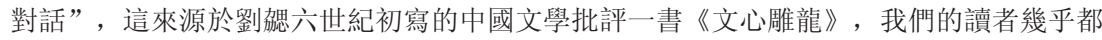
不知道這本書。其實, 我們決定把這本書作為中西方學者在寫作、詩歌、文學批評等廣泛 主題開展對話的起點, 因為這本傑作完全代表了那些在當今中國依然被分享和尊重的重要 的傳統觀點。我們的選擇一方面基於對這本著作的喜愛, 但更重要的是, 《文心雕龍》是 中國文學思想中首個、冊庸置疑的系統性網要，也是第一個系統的中國傳統文學知識分類。

關鍵詞：國際研討會, 《文心雕龍》, 對話, 文學思想, 傳統和當今中國。

\section{WXDL: A MILESTONE IN THE CONSTRUCTION of Chinese cultural identity}

In the Chinese tradition, WXDL is not only the essential reordering of the literary world as the first catalogue of literary genres and forms, but also - as Liu Xie himself declares in chapt. L:

of couplets in which metrical identity (most often four or six characters) and syntactical parallelism occur between corresponding lines. Thus, in terms of form it shows many of the same prosodic qualities of Chinese poetry. In fact, it was the style of writing favored from the late Han through early Tang" (Nienhauser 1986, 656). 
按蕧文雅之場, 環絡藻繪之府, 亦幾乎備矣。

Gallop over the course of literature, in peering into the house of the poetic art. (Wong et al. 1999, 189)

In grasping the reins on the meadows of literary graces and looping the halter in the treasure house of eloquence, I think this is virtually complete. (Owen 1992, 197)

Si è cavalcato a briglia sciolta nei campi delle Lettere, si è perlustrato in lungo e in largo il palazzo della retorica, nulla lasciando di inesplorato. (Liu Xie 1995b, 326)

Today, WXDL is unanimously regarded to be the most important work on theory and criticism in Chinese literary history; it is widely quoted as an authoritative voice in studies of literature of all periods and genres. (Richter 2012, 210)

The WXDL is an incredible work, part literary criticism, part cosmological treatise, an it is also perhaps the best guide we know on how to write well in literary Chinese. (Eoyang 2005, 587)

[...] an anomaly in the history of Chinese literary thought, and it is a systematic treatise on literature as it was conceived around the turn of the sixth century. (Owen 1992, 183)

In its work, the author, Liu Xie, provides us with a systematic classification of knowledge, as it is recorded through written documents ${ }^{3}$.

In the first chapter of his book, "Tracing the origin to the Dao (Yuan Dao 原道)” - which is a chapter with a clear cosmogonic framework - the author elaborates on the polysemy of the term wen 文, a term which is fundamental to the entire book; it is a crucial part of the same title and it occurs more than 500 times in the whole text (Lavagnino 2011). Wen, in fact, means pattern, written graph, writing system, in a very complex system of thinking, which is strongly based on the preeminence of the written text over the oral form.

As an inner power (德), pattern (文) is very great indeed, born together with Heaven and Earth. And how is this? All colors are compounded

3 Throughout its history, Chinese civilization has always based its strong cultural foundations on the Chinese system of writing. The privilege of mastering this difficult writing system allowed the scholars to become part of the élite, through the complex examination system which developed through the centuries in the form of $k e j u$ 科舉 (Wilkinson 2015, 504). 
of two primary colors, the purple that is Heaven and the brown that is Earth. All forms are distinguished through two primary forms, Earth's squareness and Heaven's circularity. The sun and moon are successive disks of jade, showing to those below images (像) that cleave to Heaven. Rivers and mountains are glittering finery, unrolling forms that give order (理) to Earth. These are the pattern (文) of the Way. Considering the radiance emitted above, and reflecting on the loveliness (章) that inhered below, the positions of high and low were determined, and the two standards were generated. Only the human being, endowed with the divine spark of consciousness (性灵), ranks as a third with this pair. And they were called the Triad [Heaven, Earth, and human beings]. The human being is the flower (秀) of the elements: in fact, the mind (心) of Heaven and Earth. When mind came into being, language was established; and with the establishment of language, pattern became manifest [明 “bright”, “comprehending”, “admitting comprehension”]. This is the natural course of things, the Way (道). (Owen 1992, 187-189)

As we read in the powerful exordium of the book, the categorization of knowledge that Liu Xie introduces pays homage to the traditional cosmologic Triad (san cai 三才): Heaven, Earth, and human beings (tian 天, di 地, ren 人), which constitutes the foundations for the structuring of the world order in traditional China. And all the text is organized following a precise hierarchy, starting with the homage to the Sage, Confucius - the great Master, the first thinker who wanted to put things in order, giving to each thing its "correct name" (zheng ming 正名) because when the correct name responds to the real nature of the thing, the world of human beings would be in peace (Analects XIII, 3) - ... or to the Sages (according to other translations ${ }^{4}$ ) and then describing the main official literary genres in "rhyme" (wen 文, yunwen 韻文), and in “prose” (bi 筆, sanwen 散文). Wilkinson $(2015,409)$ enlists 33 genres.

The literary landscape described by Liu Xie displays, fort the first time in the Chinese literary reflection and in a very systematic way, the ordering of knowledge according to three main categories: shi 史 (history), $z i$ 子 (the Masters of thought), wen 文 (embellished/poetic). And these categories under the Sui dynasty (VI A.D.) became the orthodox classification system to systemize the entire wealth of knowledge gathered in the Imperial Library, the so called “four classifications (sibu 四部) system”.

4 For the various translations of chapters titles, see Simona Gallo's contribution (pp. 99-113). 
This system through the centuries has informed the organization of knowledge and the ordering of the intellectual world in traditional China (Lavagnino 2017).

WXDL - as it clearly emerges through the flowing of chapters - is structured in a carefully thought-out systematic frame: it is written in a precise order and according to a definite program, developing different topics in a rational progression. The work is signed by a recognized author, Liu Xie, who in the last chapter, called Xuzhi 序志 (Declaration of intent), clearly expresses its scopes, boundaries, aims and purposes ${ }^{5}$.

And this work became the basis for any further development not only in the realm of literary criticism, but also in the categorization of knowledge.

For these reasons, we can now agree that WXDL, with its highly polished structure, its perfect refined language and its deep and profound content, has shaped the intellectual reflections and the critical thought of Chinese Literati, giving an invaluable contribution to the construction of Chinese cultural identity.

Although research on WXDL is mainly concerned with the literary questions raised by Liu Xie, "a considerable portion of scholarly interest has always been dedicated to the author himself" (Richter 2012, 215). We know that in the contemporary literary world of the Qi and Liang dynasties, Liu Xie (465-522) was not a major figure: he was not himself an experienced or well-known writer; as a lay-scholar in a Buddhist temple, his views on literature had not been formed in the great aristocratic salons on the day. The WXDL is said to have been composed when Liu Xie was in his thirties, and the work was fortunate in having met the approval of the most influential man of the age, Shen Yue (441-513) (Owen 1992, 183).

Shen Yue was a poet, a statesman, and an historian. He is probably best known in the history of Chinese prosody as the originator of the first deliberately applied rules of tonal euphony, called "four tones and eight defects” (si sheng ba bing 四聲八病) (Knechtges 2014, 861-870).

Much was written about the terminology adopted by Liu Xie in his book, whether it had been much influenced by Buddhist or Daoist thought. And much has been written on his literary theory. For a detailed bibliography on the subject see below ${ }^{6}$.

5 For a recent summary on this, see Knechtges 2014, 1357-1361.

6 See Wang Li's paper (pp. 115-118). 
As Stephen Owen has brilliantly pointed out,

It is difficult to properly evaluate the influence of WXDL on later generations. We know that the book never disappeared from circulation. From the Tang through the Ming dynasties there is a substantial and continuous corpus of references and quotations. (Owen 1992, 184)

During the Qing dynasty, the interest in this text grew substantially, and in modern and contemporary times, after a period of harsh criticism during the Cultural Revolution (1966-76) - the book was criticized as reactionary and feudal and banished from shelves and libraries - the text has received unparalleled attention mostly from scholars from China, Japan, Korea. And to emphasize the importance of this text, an International Association dedicated to WXDL was founded 1983 in Shandong (Zhongguo Wenxin diaolong xuebui 中國《文心雕龍》學會). A text which, as we just said, gave rise to a real discipline, a "school" ( $x$ ue 學), a "specialization” (zhuanye 專業), the so called “dragonology" (longxue 龍學), both in China and abroad. And we also have an invaluable treasure of notes, commentaries and translations in contemporary Chinese.

\section{The Symposium}

For this reason, we invited three scholars from China, "experts on Dragons” (longxuejia 龍學家) and members of the Association to participate to our Symposium: Prof. Zhang Shaokang 張少康, formerly Professor at Peking University (Beijing daxue 北京大學), and now Head of Department of Chinese Language and Literature at Hong Kong Shue Yan University (Xianggang Shu ren daxue 香港樹仁大學), Prof. Tao Litian 陶礼天, from Capital Normal University (Shoudu Shifan Daxue 首都師範大學), and Prof. Zuo Dongling 左東岭, from Capital Normal University (Shoudu Shifan Daxue 首都師範大學), Member of the Research Center of Chinese Poetry.

They all made great contributions not only on textual commentaries or critical reflections but also on bibliographical repositories.

We also invited two young sinologists coming from France, Valérie Lavoix and Marie Bizais ${ }^{7}$, who were my partners in a panel organized in

7 Unfortunately, the two French scholars were not able to send their contribution for this publication. 
Paris, in 2012 at the XIXth Conference of EACS (European Association for Chinese Studies). The title of the panel was "Uncarving the Dragon: Retrospective and Prospective Views on Wen xin diao long".

In addition to this, we have had the privilege to have with us Itala Vivan, Professor and scholar of postcolonial studies at the University of Milano, and experienced and privileged interpreter of world literatures.

More than twenty years ago, when my translation into Italian of WXDL was published, she had the patience to read the entire Italian version of the book, and then she organized a Seminar at this University, the title of which was "Forme di draghi e modelli letterari". On this occasion, Itala was able to put together some well-known Italian sinologists such as Enrica Collotti Pischel, Lionello Lanciotti, Edoarda Masi and colleagues who were experts on Western literary criticism. She had also invited some Italian poets to give their precious contributions to a common reflection ${ }^{8}$. During the Symposium, our dialogue wasn't neither easy or simple but it was very fruitful and profound. We are now very pleased to be able, finally, to put together at least some of the contribution to the Symposium together with some other materials that we hope will be useful to students and scholars on the state of the art on this topic.

\section{WXDL: THE CHALLENGE OF TRANSLATING POETIC "AMBIGUITY" 9}

As we have just mentioned, in China there has always been a lot of interest in WXDL, but in the West the book arrived quite late: the first complete translation in English was made by Prof. Vincent Yu Chung Shih and published in 1959 (Shih 1959) ... And for more than a generation Western students and scholars of Chinese Literature have had to rely on this bilingual translation. All the Western specialists recognize that

while extremely useful this edition was very much in need of revision, given the enormous progress made in LX studies in the last half century. Shih's translation, while serviceable as a rough guide to the meaning of the original was, however, leaden and paraphrastic rather than evocative and metaphorical. (Eoyang 2005, 588)

8 See Lavagnino et al. 1996.

9 When using this term, I refer to William Empson's eminent work, Seven Types of Ambiguity (Empson 1930). 
Shih in 1983 published a new edition of the book, adding the Chinese text, but without providing any revision of his English translation, and without any updating of the critical framework.

It is worth here mentioning the titles of the complete translations that have been published in Western Languages.

In Italian there is my translation, Liu Xie, Il tesoro delle Lettere. Un intaglio di draghi, published in 1995 (Liu Xie 1995b). The same year, Alicia Relinque Eleta published her Spanish translation: Liu Xie, El corazòn de la literatura y el cincelado de dragones (Liu Xie 1995a).

In 1999, the Hong Kong University Press published The Book of Literary Design, a translation into English by three scholars from the University of Hong Kong: Siukit Wong, Allan Chung-hang Lo and Kwong-tai Lam; the description on the back cover of the volume reads as follows:

[...] a fresh translation of the WXDL that is once authoritative and elegant. It may well be regarded as a standard reference by students of sinology and comparative literature. This new English translation is very useful indeed, straightforward and easy to understand, but in some ways, is too easy, and does not do justice to the richness and the depth of the original text. (Wong et al. 1999)

More recently, the new interest on longxue in Mainland China produced two new complete translations, one into English (Yang 2003): DragonCarving, published in 2003 Beijing by the Foreign Language Teaching and Research Press. Yang Guobin figures as the translator into English, from the previous translation into modern Chinese made by Zhou Zhenfu in 1986. And the most recent one in French (Chen 2010) entitled L'essence de la littérature et la gravure des dragons, was published in Beijing in 2010, edited and translated by Chen Shuyu, a Chinese scholar from Beijing, specialized in comparative literature; this version seems quite concise and easy, without deepening too much into the philological and critical aspects.

I want now to briefly focus on the translation made by Yang Guobin (2003); one of the authorities on English translations of Chinese texts, Eugene Eoyang Chen, said that Yang's translation has filled a gap:

This lacuna in Chinese aesthetics has been filled by a more recent 2003 bilingual edition, part of the Library of Chinese Classics Series, published by the Foreign Language Teaching and Research Press, featur- 
ing an English translation by Yang Guobin, based on a previous (1986) translation in modern Chinese by Zhou Zhenfu, a celebrated authority among the long xuejia, author of important studies and commentaries ${ }^{10}$. To read the original in the light of the modern Chinese version, and then the English translation is an interesting exercise in genre study [...]. The modern Chinese version is not a translation so much as it is a commentary, often quoting the original verbatim, and modernizing certain idioms and constructions which are no longer current. (Eoyang 2005, 589)

In fact, we should remember that, starting from the Eighties, we have quite a few intralingual translation of WXDL in the contemporary and colloquial Chinese, and this is perfectly understandable, in order to fill the gap which was created by the repressive measures adopted during the Cultural Revolution: it was absolutely necessary at the time to make WXDL easily understandable to the ordinary Chinese reader ${ }^{11}$.

The work of interpretation seems more evident in Yang Guobin's English version, which harkens to different reference points, and employs a different palette of nuances. Where the original embodies concepts, which may be understood by a native, if only by familiarity, the modern Chinese version needs merely to quote the original rather to translate it whereas the English must venture semantic equivalencies which cannot be the ipsissima verba. In this way, the modern Chinese may be less prone to 'inaccuracies' but it does not fully address problematic phrases and passages as the English must. (Eoyang 2005, 589)

It is worth here to make just a short remark: the English and French translations were all made by Chinese native scholars, while the Italian and the Spanish ones by Western scholars ...

Among the challenges of translating Chinese classical literature into English ${ }^{12}$ or into another Western Language, one important aspect involved in the translation process is the concept of yi jing 意鏡, that James

10 For a synthesis of the contributions of Zhou Zhenfu, refer to "The Revival of Studies on Wenxin diaolong after the Cultural Revolution: the Contribution of Some Scholars" (pp. 25-42).

11 For the invaluable contribution of some Chinese scholars to the revival old studies on WXDL see my abovementioned contribution.

12 David Hawkes proposed that the least reproducible aspect of Chinese poetry is the formal one such as the tonal pattern, meter and rhyme (Hawkes 1971, 90-115). 
Liu called "world" of poetry (Liu 1962). The expression literally means "the realm of meaning" ( $y i$ 意 “idea”, jing 鏡 “realm” or "sphere”). And we can easily apply to our task the reflections on translating poetry proposed by Tang Yanfang:

As a literary notion, yi jing refers to an ineffable and meaning-laden artistic space that the poet intently constructs through a combination of his thoughts and feeling with the object or scene he depicts in his poem. As an artistic space yi jing captures a feature or an effect common to all poetry because all poetry invites readers to enter its world and savor its meanings and artistic beauties. (Tang 2014, 188)

And one of the problems that we, Western translators, meet in our work lies precisely here: in many cases for us it is absolutely necessary to make definite linguistic choices where a Chinese translator, even the contemporary Chinese scholar who makes the intralingual translation, does not need any further explanation because the meaning of the text is perfectly transparent. We are obliged to bring to light and to simplify, even at times in the most unsatisfactory way, the marvelous, poetic ambiguities and the richness of significance that are embedded in the concision of classical Chinese language. Something that for the modern Chinese intralingual translator is in many cases almost taken for granted needs difficult and sometimes exhausting over-explanations for a Western translator: we have to explain, and explain and explain yet again the rich cultural context through footnotes and references ...

In fact, if the task of translating across cultures is particularly hard referred to the Chinese, for a text like WXDL it seems to become even harder as we will see in the next section of this contribution.

\section{WXDL: AN UNTRANSLATABLE TITLE?}

One of the best examples of these difficulties is given by the title itself: Wen xin diao long.

"The title is made up of two word-compounds, the first of which is unprecedented wenxin, while the second diaolong has enjoyed a relatively long history as metaphor and stereotype" (Lavoix 2000, 201). The two compounds are precisely defined by the author at the end of the work (chapt. L). The first, wenxin, is largely polysemic: 
[...] "the literary mind", or "to take the mind literary/cultivated/ patterned", or "to consider mind regarding the question of wen", or (translating Liu Xie's explanation literally) "the use/effort of mind in literature". The second element, diaolong, literally "carve dragons", refers in some way to the craft of literature. It seems to be a positive transformation of an old pejorative term for literary craft diao chong 雕蟲, "to carve insects" (a "dragon", as a reptile, was classified under the general category of chong, "insects", but his position in that generally lowly category raises it to the sublime). Liu Xie clearly wants to dissociate his idea of craft from the pejorative associations that hover around all the terms for craft in Chinese. The complete title may be read as a single predicate, something like "the literary mind carves dragons" [...]. Or with a slightly different emphasis, the title may be taken as two separate coordinate clauses, as Vincent Shih translates "The Literary Mind and the Carving of Dragons". The English reader need only to keep in mind that there is a potential tension between these two elements and that the second element, "dragon-carving", is more problematic, a hopefully positive term for ornamental craft, which Liu Hsieh alternately attacks and defends throughout the work. (Owen 1992, 185)

The invention of Liu Xie consists here in seeking the metaphor of "chiselled dragon" to identify the nature of the work as is understood almost unanimously by commentators.

An interesting opinion is expressed by Eugene Chen Eoyang:

There is no question about the "carving of dragon", it is the "literary mind" that bothers me. Although it has the sanction of Vincent $\mathrm{Yu}^{-}$ chung Shih and James J.Y. Liu, and despite the fact that it reads well in English, [unfortunately not so well in Italian: "La mente letteraria" [...], "Literary Mind" doesn't really capture the sense of Wenxin which really means "manifestation of mind". The parallel with carving the dragon is extremely important: just as the dragon is brought out, so literature brings out what is in the heart. I cannot claim to have found the perfect translation either, but there are times when I think that something like "Carving Dragons, writing out our feelings" would serve the original better. (Eoyang 2005, 589)

We can admit that that the title for a Chinese reader could be understandable, and full of hidden meanings. As Liu Xie himself says in his Xuzhi - "Ordering (my)intentions" is the translation of the title of this chapter proposed by Dinu Luca (Luca 2010, 4) - at the end of his work: 
夫丈心誼。言為文之用心也。昔涓子琴心。王孫巧心。心哉美矣。故用之焉。

The patterned/literary mind means the use of mind (or "intense effort") in writing. Once there was Juanzi's "Mind of the Zither" and Wangsun's "Artful Mind". Mind is a fine thing indeed, and thus I have used it here. (Owen 1992, 292)

Liu Xie opens this chapter with a strong echo of the "Preface" to Lu Ji's The Poetic Exposition of Literature (Wenfu 文賦): “Whenever I consider what is made by a person of talent (cai 才) there is something within me that allows me to grasp their strenuous efforts (or use of mind yongxin 用心)” (Owen 1992, 293). And just as Lu Ji had done one century before him, Liu Xie plays with words, referring to "mind" both as a term in the title of the two books ("Mind of the Zither" and "Artful Mind") and as a faculty: "the use of mind" or an intense effort, though Owen observes that

Lu Ji was thinking of the "strenuous effort" in literary work, whereas Liu Xie considers it in composition of his own critical work. Liu Xie, concerned always with the value of writing about literature and with asserting the superiority of his own work to that of his predecessors, begins with a false genealogy, implicitly setting the title of his work in a set with two other, largely unknown works, while avoiding mentioning $\mathrm{Lu} \mathrm{Ji}$, to whom he owes so much. (Owen 1992, 293)

\section{Conclusions}

As we have seen, to translate this title is a puzzle without any satisfying solution.

In my opinion, in this title there is an ambiguity which is in fact impossible to resolve in any possible translation in a Western language. And this ambiguity resides precisely in the manifold meaning of the character $x i n$. As we all know, xin could mean either what I call the personal, subjective (zhuguande 主觀的) component of the writer: his mindheart, and this element is best illustrated by the first explanation given by Liu Xie: yongxin 用心, that is "the use of the mind" or "the intense effort".

But also, as it is still now one of the meanings of xin in contemporary Chinese: hexin 核心 (core/kernel/heart/center/nucleus), a component that I would call objective (keguande 可觀的): the crystallization of the "use of mind" in written works, in books: from this meaning, we can better 
understand the second part of Liu Xie's explanation, that recalls the titles of the two books (now lost) "Mind of the Zither" and "Artful Mind". We can understand then that the expression wen xin keeps at the same time the double meaning of the "Literary mind" (the efforts of the heart-mind in writing literature) and the Core, the Summa, the Treasure of literature.

As we can see ${ }^{13}$, some translators have then opted for the subjective component, others - and I'm among then - the objective one. Finally, in my Italian translation I opted for a title which in some ways echoes the Western medieval rhetoric: Thesaurus delle Lettere. But now, after more than twenty years since the publication of the book Il tesoro delle Lettere. Un intaglio di draghi, I'm still searching for my ideal translation.

13 Here is a list of the translations of the title:

Alexéiev B., "Le coeur de la littérature en dragon sculpté" (Alexéiev 1937, 24); Bertuccioli G., "Gli ornamenti dello spirito letterario" (Bertuccioli 1969);

Chen Shuyu, L'essence de la littérature et la gravure des dragons (Chen 2010);

Eoyang E., "Carving Dragons, writing out our feelings" or "Carving Dragons, Manifesting Meaning” (Eoyang 2005, 588);

Fang A., "Dragon-carving on the Core (or Heart) of Literary Art" or "An Elaborate Presentation of the Quintessence of Literature" (Fang 1959, 713);

Gibbs D., "The Genesis and Artistry of Literature" (Gibbs 1970, 85);

Hightower J.R., "A Serious and Elegant Treatise on (the Art or Secret of) Literature” (Hightower 1959, 284);

Idema W. and Haft L., "The literary heart and the carving of dragons, i.e. the form and the content of a literary work" (Idema and Haft 1997, 111);

Jin S., "Le cœur du wen en dragon sculpté" (Jin 2013, 84);

Lanciotti L., "Segreti per il successo in letteratura" (Lanciotti 2007, 95);

Lanciotti L., "Lo spirito letterario e lo scolpire i draghi" (Lanciotti 2010, 225);

Lavagnino A.C., Il tesoro delle Lettere. Un intaglio di draghi (in Liu Xie 1995b);

Liu J., "The Literary Mind: Elaborations" (Liu 1975);

Masi E., "Arabeschi sulla mente letteraria" (Masi 2009);

Owen S., "The literary mind carves dragons" (Owen 1992, 85);

Pimpaneau J., "L'esprit de la littérature et l'ornementation ouvragée" (1989, 109);

Wixted J.T., "Elaborations on the Essence of Literature" (1983, 248);

Yang G., Dragon-Carving and the Literary Mind (Yang 2003);

Yang G. and Yang H., "Carving a Dragon at the Core of Literature" (Yang and Yang 1962, 58). 


\section{REFERENCES}

Alexéiev, Basile. 1937. La littérature chinoise. Six Conférences au Collège de France et au Musée Guimet (nov. 1926). Paris: P. Geuthner.

Bertuccioli, Giuliano. 1969. La letteratura cinese. Firenze: Sansoni; Milano: Nuova Accademia.

Dinu, Luca. 2010. "Re-figuring Liu Xie's Carpet: On the Rhetoric of the Wenxin diaolong". Asian and African Studies XIV (3): 3-18.

Empson, William. 1930. Seven Types of Ambiguity: A Study of Its Effects on English Verse. London: Chatto and Windus.

Eoyang, Eugene Chen. 2005. "Review: Dragon Carving and the Literary Mind". China Review International XII (2): 587-589.

Fang, Achilles. 1959. "Review: Wenxin Diaolong 文心雕龙. The Literary Mind and the Carving of Dragons (Vincent Yu-chung Shih)". The Times Literary Supplement, December 4: 731.

Gibbs, Donald A. 1970. "Literary Theory in the Wen-bsin Tiao-lung”. PhD Dissertation, University of Washington.

Guiheux, Gilles, Christine Lamarre, and Soline Suchet, eds. XIXth EACS CONFERENCE. Paris, 5-8 September. Book of Abstracts. Paris: Université Paris Diderot - INALCO - BULAC.

Hawkes, David. 1971. "Chinese Poetry and the English Reader". In The Legacy of China, edited by Raymond Dawson, 90-115. London: Oxford University Press.

Hightower, James Robert. 1959. "Review: The Literary Mind and the Carving of Dragons by Liu Hsieh, a Study of Thought and Pattern in Chinese Literature". Harvard Journal of Asiatic Studies 22: 280-288.

Idema, Wilt, and Lloyd Haft. 1997. A Guide to Chinese Literature. Ann Arbor: Center for Chinese Studies, University of Michigan.

Jin Siyan. 2013. "Musicalité de la poésie selon Liu Xie dans le Wenxin diaolong 文心雕龍 (Le Coeur du wen en dragon sculpté)". Dans Promenade en Chine poétique, édité par Siyan Jin et Lise Bois, 75-84. Arras: Artois Presses Université.

Knechtges, David R., and Taiping Chang. 2010. Ancient and Early Medieval Chinese Literature. Part I. Leiden - Boston: Brill.

Knechtges, David R., and Taiping Chang. 2014. Ancient and Early Medieval Chinese Literature. Part II. Part III. Part IV. Leiden - Boston: Brill.

Lanciotti, Lionello. 2007. La letteratura cinese. Roma: ISIAO.

Lanciotti, Lionello. 2010. "La letteratura cinese dalla caduta degli Han alla metà del XIX secolo”. In La Cina II. L'età imperiale dai Tre Regni ai Qing, a cura di Maurizio Scarpari, 719-764. Torino: Einaudi. 
Lavagnino, Alessandra C. 2017 (forthcoming). "A Chinese régard oblique”. Asiatische Studien 71.

Lavagnino, Alessandra C., Itala Vivan, Lionello Lanciotti, e Marica Larocchi. 1996. "Il tesoro delle lettere. Un intaglio di draghi". Culture 10: 7-27.

Lavoix, Valérie. 2000. "Un dragon pour emblème. Variations sur le titre du Wenxin diaolong”. Études chinoises 19 (1-2): 197-247.

Liu, James J.Y. 1962. The Art of Chinese Poetry. Chicago: Chicago University Press.

Liu, James J.Y. 1975. Chinese Theories of Literature. Chicago: University of Chicago Press.

Liu Xie. 1959. The Literary Mind and the Carving of Dragons: A Study of Thought and Pattern in Chinese Literature. New York: Columbia University Press [Eng. transl. Vincent Yu-chung Shih].

Liu Xie. 1983. The Literary Mind and the Carving of Dragons: A Study of Thought and Pattern in Chinese Literature. Revised bilingual edn. by Vincent Yu-chung Shih. Hong Kong: The Chinese University of Hong Kong University Press.

Liu Xie. 1995a. El corazòn de la literatura y el cincelado de dragones. Granada: Comares [trad. esp. Alicia Relinque Eleta].

Liu Xie. 1995b. Il tesoro delle Lettere. Un intaglio di draghi. Milano: Luni Editrice [trad. it. Alessandra C. Lavagnino].

Liu Xie. 1999. The Book of Literary Design. Hong Kong: Hong Kong University Press

[Eng. transl. Siu-kit Wong, Allan Chung-hang Lo, Kwong-tai Lam].

Liu Xie. 2003. Dragon-carving and the Literary Mind. Beijing: Foreign Language Teaching and Research Press [Eng. transl. Yang Guobin].

Liu Xie. 2010. L'essence de la littérature et la gravure des dragons. Beijing: Éditions en Langues étrangères [trad. fr. Chen Shuyu].

Liu Xie and Zhou Zhenfu, eds. 1986. Wenxin Diaolong Jinyi 文心雕龍今譯. Beijing: Zhonghua shuju.

Masi, Edoarda. 2009. Cento capolavori della letteratura cinese. Macerata: Quodlibet.

Nienhauser, William, ed. 1986. The Indiana Companion to Traditional Chinese Literature, vol. 2. Bloomington: Indiana University Press.

Owen, Stephen. 1992. Readings in Chinese Literary Thought. Cambridge: Harvard University Asia Center.

Pimpaneau, Jacques. 1989. Histoire de la littérature cbinoise. Arles - Paris: Philippe Picquier.

Richter, Antje. 2012. "Empty Dreams and Other Omissions: Liu Xie's Wenxin Diaolong Preface". Asia Major 25 (1): 83-110.

Tang Yanfang. 2014. "Translating across Cultures: Yi Jing and Understanding Chinese Poetry”. Intercultural Communication Studies XXIII (1): 187-202.

Wilkinson, Endymion. 2015. Chinese History: A New Manual. 4th edn. Cambridge London: Harvard University Press. 
Wixted, John Timothy. 1983. "The Nature of Evaluation in the Shib-p'in (Gradings of Poets) by Chung Hung (A.D. 469-518)". In Theories of the Arts in China, edited by Susan Bush and Christian Murck, 225-264. Princeton: Princeton University Press.

Yang Hsien-yi and Yang Gladys. 1962. "Carving a Dragon at the Core of Literature". Chinese Literature 6: 58-71.

Zurndorfer, Harriet T. 2013. "The Passion to Collect, Select, and Protect: Fifteen Hundred Years of the Chinese Encyclopaedia”. In Encyclopaedism from Antiquity to the Renaissance, edited by Jason König and Greg Woolf, 505-528. Cambridge: Cambridge University Press. 